TABLE 1 - Stomach Contents of Brook Trout and Rainbow Trout

\begin{tabular}{|l|c|c|c|c|}
\hline Brook Trout & $\begin{array}{c}\text { No. of fish } \\
\text { sampled }\end{array}$ & $\begin{array}{c}\text { Aver. stomach } \\
\text { contents/fish }\end{array}$ & $\begin{array}{c}\text { Range of } \\
\text { stomach contents }\end{array}$ & $\begin{array}{c}\text { Total contents } \\
\text { analyzed }\end{array}$ \\
\hline Baseline Creek & 16 & $0.64 \mathrm{ml}$ & $0.1-1.5 \mathrm{ml}$ & $10.3 \mathrm{ml}$ \\
Hardisty Creek & 3 & $1.36 \mathrm{ml}$ & $1.0-2.0 \mathrm{ml}$ & $4.1 \mathrm{ml}$ \\
\hline Rainbow Trout & & & & \\
\hline \hline Baseline Creek & 3 & $1.03 \mathrm{ml}$ & $0.7-1.4 \mathrm{ml}$ & $3.1 \mathrm{ml}$ \\
Hardisty Creek & 16 & $0.63 \mathrm{ml}$ & $0.2-2.0 \mathrm{ml}$ & $10.0 \mathrm{ml}$ \\
\hline
\end{tabular}

pared to rainbow trout. Therefore, I feel that both could be stocked in the same lake or stream, providing there are a wide variety of organisms for food.

\section{ADDITIONAL RECORDS OF THE RED-SIDED GARTER SNAKE IN SASKATCHEWAN}

D. M. SECOY, Department of Biology, University of Regina, and P. RAMAEKERS, Saskatchewan Department of Mineral Resources, Regina, Saskatchewan.

The Red-sided Garter Snake (Thamnophis sirtalis parietalis) has been reported in Saskatchewan at Estevan and Amisk Lake. ${ }^{2}{ }^{1}$ It has also been seen in the Cypress Hills (personal communication, members of the Regina Natural History Society). We hereby report sightings of this species south of Lake Athabasca at $110^{\circ} 00^{\prime} \mathrm{W}, 58^{\circ} 07^{\prime} \mathrm{N}$ on
'LANGLER, K. 1972. Freshwaster fishery biology. C. Brown Co. Publishers, Dubuque, lowa.

2NEEDHAM, J. 1976. A guide to the study of fresh-water biology. Holden-Day, Inc., San Francisco.
June, 1978 on a boulder esker near a marsh, and another $3 \mathrm{~km}$ south of Cluff Lake on 19 August, 1979, on a south-facing rocky slope. Both were sightings of single animals.

This species has been reported along the Birch River draining into Lake Athabasca in Alberta, and at Fort Smith, Northwest Territories. ${ }^{1}$ Therefore, its presence in the boreal forest south of Lake Athabasca in the Athabasca basin is not unexpected.

'LOGIER, E. B. S. and G. C. TONER. 1961. Check List of the Amphibians and Reptiles of Canada and Alaska. Contrib. No. 53, Life Sciences Div., Royal Ontario Museum.

${ }^{2}$ NERO, R. W. 1957. Observations on a garter snake hibernaculum. Blue Jay 15:116-118. 